UDC $141.132: 165.742]: 316.32$

Doi: https://doi.org/10.30839/2072-7941.2019.177708

\title{
HUMANISTIC TYPE OF RATIONALITY AS A FACTOR OF THE FORMATION OF CO-EVOLUTION-INNOVATION STRATEGY FOR SUSTAINABLE DEVELOPMENT OF MANKIND
}

\author{
(C) KOZLOVETS, M. A. \\ Zhytomyr State University named after Ivan Franko (Zhytomyr, Ukraine). \\ E-mail: mykola.kozlovets@ukr.net, ORCID iD: 000-0002-5242-912X \\ (C) HOROKHOVA, L. V. \\ Zhytomyr State University named after Ivan Franko (Zhytomyr, Ukraine). \\ E-mail:_glv@ukr.net, ORCID iD: 0000-0002-5114-523X \\ (C) MELNYCHUK, V. V. \\ Zhytomyr National Agroecological University(Zhytomyr, Ukraine). \\ E-mail: vikam1804@gmail.com, ORCID iD: 0000-0003-1569-3201
}

Annotation.Topicality of the study lies in the fact that modern rationality as a significant achievement of civilization is simultaneously becoming a real threat to the mankind.Science, undertaking a humanistic mission, at the same time dehumanizes what it was aimed at: the system of values, education and culture.Acquired knowledge is often used to destroy the environment and humanity, and not for progress and well-being.Disruption of the harmony of natural, social and spiritual, underestimation of the anthropocentric dimension of scientific rationality put Homo sapiens on the brink of being.Recently, in philosophical and social thought, the problem of the ways of forming a new humanistic world attitude and humanistically oriented science and ethical rationality has acquired particular urgency.Analysisoftheliterature.Scientific works of foreign and native authors, who began the study of this problem, are used:R. Andryukaitene, V. Vernadsky, M. Vishnevsky, V. Voronkova, J. Habermas, A. Gritsanov, I. Kasavin, A. Kornienko, K. Korsak, A. Lazarevich, V. Lectorkog, A. Mercier, R. Nugaev, V. Ratnikov，O. Sosnin, V. Stepin, J. Nikitina, M. Ratz, N. Reimers, A. Tolstoukhov, O. Tsira, V. Shvyrev, V. Shuper.Purposeofthearticle-philosophical understanding of the new rationality as a factor in the formation of a coevolution-innovation strategy for themodern world development.Theobjectiveofthestudyisananalysis of the essence of rationality, the characteristics of its main features and role in the formation of a coevolution-innovation strategy for the sustainable development of the mankind.The methodology of the study is based on an interdisciplinary approach, integrates modern practices of philosophy, philosophy of science, epistemology, ecology, ethics and axiology.Comprehension the complex problems of the rational / irrational, evolution / co-evolution, crisis / sustainable development dichotomy and their influence on the humanization of scientific knowledge was encouraged by the principles of historicism and global evolutionism, the dialectical method, methods of abstraction, generalization and conceptualization, as well as the methodology and principles of synergetics.The conclusions :The article studies the essence of rationality and the limitations of its current concept, the causes and features of the crisis of rational awareness of the modern world, due to the dehumanizing role of scientific and technological progress.It justifies the thesis that the situation can be changed by giving the scientific progress of the humanistic direction, forming the anthropocentric dimension of scientific rationality.Humanity must resolve an issue of rationality from the position of the humanistic world outlook and create a new model of science. The basis for solving this problem may be the modern understanding of humanism, which, in turn, will serve as the basis for the emergence of a new type of

Humanistic type of rationality as a factor of the formation of co-evolution-innovation strategy for sustainable development of mankind 
rationality.It is the rationality based on humanism ethics that can become the core of the coevolution and innovation strategy for the sustainable development of mankind.Study findingsare that it is humanistic rationality, based on co-evolutionary and innovative ethics, that provides global society as a system with a high level of stability regarding the destructive impact of crises, the formation of an innovative orientation, taking into account the need to bridge the potentially dangerous gap between modern civilizations - the scientific, technological and social humanistic ones.

Key words: rationality,irrationality, science,scientific rationality, types of rationality, coevolution,innovation, scientific and technological progress, post-classical humanism.

Problem solving in general and its connection with important scientific or practical tasks

\section{Humanity today faces} unprecedented global changes: environmental, economic, cultural, political, and social.At the same time, on the verge of XX-XXI anthropogenic civilization has faced problems that indicate a large-scale crisis, which is reflected in the threats of survival of the human race as a qualitatively peculiar degree of animate natureevolution, the danger of the destruction of the biosphere, as well as in the problems generated by modern information technologies. The information civilization comprehensively, deeply, far from always has a positive effect on human development.Consciousness of people is becoming more superficial, simplified.The hopes that relied on the stabilizing features of such spheres as knowledge, science, information, their influence on the prevention of the consequences of the systemic crisis, have misplaced.The previous mechanisms of scientific sphere management, which led to enormous technological progress of mankind, are becoming today a threat to its existence, accompanied by dehumanization. And science itself is found in a state of crisis, because its epistemological possibilities, and, consequently, the potential of modern scientific rationality as signs of science and the way of development of the world appeared to be not sufficiently developed to prevent the emergence of a crisis situation.Under such conditions, the development of an optimal strategy for a constructive solution to the crisis is impossible without the formation of a new concept of rationality, which is the basis of the modern paradigm of world order.

An analysis of recent researches and publications from which the author of the problem is based on the solution of this problem

An analysis of global scientific and technological changes, their socio-anthropological consequences and ecohumanistic prospects of humanity, criteria and imperatives of sustainable development is one of the most important topics in the system of socio-philosophical

knowledge.Researchers record the contradiction between the new realities of existence and the established (outdated) forms and methods of scientific and rational comprehension of the world.The fourth industrial revolution begins, in which technology will play an increasingly important role both as a blessing and as a challenge to the existing way of life.The risk of the use 
of new technologies that have a multipurpose purpose and make it possible to form a new value and ideological space of the zones of influence and interests of other states is becoming more and more obvious.

A thorough scientific and philosophical study of various aspects of rationality problem in foreign and native science is primarily due to the names of such scholars as R. Andrikuyten, V. Vernadsky, P. Vodopianov, M. Vyshevsky, O. Hrytsanov, An. Kornienko, A. Kornienko, A. Lazarevich, V. Lektorsky, M. Moiseev, A. Pecces, I. Prigogine, M. Reimers, V. Steopin, Yu. Nikitina,
A. Schweizer, V. Shuper Ukrainian
V. Voronkova, E. Bystrytsky, O. Gomilko, T. Gardashchuk, A. Yermolenko,

J. Habermas, M. Kiselev, S. Krymsky, V. Ratnikov, A. Sosnin, A. Tolstoukhov, Yu. Tunitsa, O. Tsira. The works of these researchersanalyzenot only rationality itself and its essential manifestations, but also contain criticism of scientific and rationalized forms of human thinking. The authors fairly refer to a number of negative features of the industrial society the facts of unsuccessful exploitation of scientific knowledge in production interests, attempts to use the imperatives of science for political and ideological purposes, the construction of complex methodological techniques, which are based on the completeness and completeness of scientific evidence.It is substantiated that with the transition to post-industrial development the attitude to science, value and self- value of knowledge in general is changing.Despite the study of a number of aspects of this problem, it remains unsystematized, as there is an interest in researching rationality as that which is accompanied by insufficient attention to its crisis and its impact on the co-evolutionary and innovative development of the modern world.

\section{Presentation of the main} research material with the discourse of the received scientific results

Since the formation of science as a social institution, its role in society has been growing steadily. At the same time, two parallel processes were observed: on the one hand, thanks to science and technology, the achievements of mankind in various fields multiplied, and on the other hand, the number of problems with which society could not and cannot cope even now increased.Scientists note that the current crisis situation is only a reflection of the deeper crisis of rationalism, which has destructive consequences for the new millennium society.The most obviously devastating impact of the systemic crisis is observed in the current concept of rationality, which led the world to the loss of its integrity and unity.The rationality of the postindustrialist era is subject to serious changes, and its fundamental principles are amenableto the deforming influence of unprecedented in scale transformations.Thus, the Ukrainian philosopher A. Tolstoukhov, questioning the rationality of the behavior of individuals and groups in the post-

Humanistic type of rationality as a factor of the formation of co-evolution-innovation strategy for sustainable development of mankind 
industrial, post-modern society, rightly notes, that "the very foundations of rationality democracy, law, science - are subject to erosion.Survival and resistance to mega-transformations of the global social context become the dominant motivators of behavior" [1,p. 49-63].

If we compare the current situation with that which arose in European civilization after the New Age and the epoch of the Enlightenment, then it becomes clear why, over time, spiritual and moral values became less and more important for a significant part of society.This shift is explained by the fact that scientific knowledge, which occupied the place of religion in the system of core values, in many cases did not become an existentialindividual value, but served as an empirically necessary system that facilitated human activity in many spheres.It has not become universally significant both at the individual level and in the social context of value.Society ceased to be united in value-ideological terms. Some began to believe in science, others - in religion, and others despaired of both the first and the second.Skepticism has become so significant as faith in certain values.

Acknowledging the pathos of the evolution of the reformatting of social structures and of ahumanbeing as one of the most important characteristics of the XIX-XX centuries., I. Kasavin, V. Lyktorsky and V. Shviryov emphasize the change in the content of the concept of "rationality": "Rationality is increasingly beginning to be understood not as something spiritual and disinterested, but as something that serves the success of an activity, helps to regulate human relations. The measure of rationality began to be applied to all types of vital activity, and they were understood and evaluated precisely from this point of view"[2, p. 142].

Denial of the current concept of rationality is now becoming increasingly large, due to the aggravation of crisis phenomena in society. One of the landmark signs of the growing crisis was the formation of a specific consciousness, which was also characteristic of the crisis period of the rationalistic concept in the 19th and 20th centuries, aimed against the role of science as the dominant and decisive force of social development.Thus, M. Reimers and V. Schuper, acknowledging the conflict of science and ethics, note:"In recent decades, science has become a target for acute and far-fetched sound criticism, and not as a social institution, as much imperfect as all the rest ... but as knowledge of objective reality, understood as a set of clearly verifiable statements"[3, p. 68-75].But the Swiss philosopher Andre Mercier believes that "science has become aggressive and seeks to occupy a leading place in the spiritual life. It dominates, turns into a monopoly, easily ignores all the rest" $[4, \quad$ p. 9].As reaction to these problems, antisecentist directives are being formed that orient the mass consciousness to the limited capacity of science, to the perseption of science as a force hostile in nature to the nature of man, and therefore, responsibility for all social catastrophes is placed on it.At the same time, critical assessments of the post-industrial era, science and scientific rationality are accompanied 
by an attempt to rationally justify strategies for the society development.

The narrow specialization of scientists within individual sciences leads to the fact that new facts are often analyzed outside of their interrelation with other spheres,as a result, the significance of scientific discoveries risks remaining closed in the narrow range of specialized knowledge.The outlined features are also characteristic of the development of socio-humanities, which does not allow to construct a generalized concept that would explain modern changes in the life of people and society in general.It should be noted that the question of the crisis of the humanities, about their failure to adequately describe the phenomena of culture, religion, consciousness, psyche, appeared on numerous occasions.Each time this crisis was associated with the fact that the classical scientific approach "cut off" the specifics of humanitarian phenomena, assimilating them to natural phenomena. The proposed new approaches that tried to preserve this specificity were not sufficiently scientific in the sense of their relevance to the criteria of classical science - objectivity, rationality, repeatability, predictability, etc.Moreover, recently we are increasingly dealing with scientific knowledge not so much with real as with possible objects and even worlds.

Analyzing the directions of modern trends in the interpretation of rationality, scientists, according to the classification proposed by V. Stephen, identify three main stages in the development of rationality concepts:classical, non-classical and post-classical rationality, which in the theory of knowledge correspond to different forms of idealization of the subject of knowledge and foreshadow different types of reflection over activity.According to V. Steopin, classical science and its methodology are abstracted from the activity nature of the subject; in a nonclassical, this nature already appears in an explicit form, and in post-classical it is supplemented by the ideas of the sociocultural constraint of science and the subject of scientific activity [5, p. 5-17].Types of scientific rationality interact, and the appearance of the next does not contradict the previous, but only limits the scope of its action.Emphasizing the importance of post-classical rationality, the philosopher drew attention to the fact that the subject of knowledge within post-classical science should not only "master the ethos of science", "focus on non-classical ideals ... proofs of knowledge," but also "to carry out a reflection on the values of scientific activity, expressed in scientific ethos.Such reflection involves the correlation of the principles of scientific ethos with social values, represented by humanistic ideals, and then the introduction of additional ethical obligations in the study and technological development of complex human-dimensional systems" [5, p. 5-17].It is obvious that the development and analysis of complex self-organized systems within postclassical science generates the need for ethical evaluation of research programs.All this testifies to the emergence of a number of new

Humanistic type of rationality as a factor of the formation of co-evolution-innovation strategy for sustainable development of mankind 
problems not only of a methodological nature, but also of an ideological one, which determines the existence of conditions for the paradigmatic transformation of the scientific tradition.

Back in the 70s of the twentieth, Y. Habermas posed the thesis about the crisis of the "old" rationality as formally focused on quantitative criteria.This rationality is a scientific and practical rationality. The philosopher justifies the need for humanization of scientific and practical rationality by appealing to the culture, the sphere of personal manifestations, the sphere of communication.He defines his concept as one that allows one to find an opportunity to rationalize rationality itself.As an alternative to modernist theories that come from either the "old" rationality or are ineffectively criticized and deconstructed, J. Habermas proposes his own original concept of "communicative mind", "communicative rationality", which, in his opinion, will allow finding an opportunity for rationality, will represent "potential for reason" and is oriented towards understanding, towards the development of the theory of knowledge by other means [6, p. 31-32, 45].

The current situation leads to a cautious, suspicious attitude to science, forms an understanding that the traditional type of rationality has exhausted its capabilities and has become dangerous for a person.In science focused to this type of rationality, almost all human, humane is excluded from the cognitive process, and exclusively objectivistic scientific knowledge, separated from man, is soulless knowledge.Hence, the rationality generated by intelligence was suppressed by the mind itself. Today it is obvious that the logical and epistemological model of science, based on a similar type of rationality, should replace another model of science based on the humanistic type of rationality[7, p. 25].

The principal significance of this problem is due, firstly, to the fact that science has become the basis for that form of rationality which functions in a large number of countries, especially European ones;and, secondly, the increasing role of science and its influence on other spheres of life, which intensifies the crisis in the spiritual and moral sphere.Therefore, it can be argued that radical changes in the worldview that took place in European culture from the seventeenth century have led to problems that remain unresolvedto this day.The problem of science and spirituality is closely linked with the antithesis "science -values", because human values are an essential element of its spiritual world.And if science is aimed at the knowledge of laws, then the world of values in general and of spiritual ones, in particular, does not obey them (laws).Spiritual complements natural and social, but only at the theoretical and methodological level.In fact, at certain stages of the development of mankind in different traditions, the world of scientific knowledge is not always harmoniously combined with the world of moral, religious and spiritual values. This circumstance has always excited sophists, but it becomes of particular relevance during the 
transition from one paradigm of knowledge to another.Scientific knowledge at all stages of development was based mainly on the intellect, oriented mainly on the ability of rationally-conceptual reflection of reality.Science, based on intelligence and using human abilities, builds different models, pictures of the world that have empirical foundations.

Considering the unique as a form of movement of rationality, A. Tsyra notesthat if in classical rationality, unique principles were unambiguity, clarity, obviousness, in non-classical relativity, complexity, randomness, complementarity, then in non-classical, non-linearity, chaos, self-organization, and openness of systems became determinative principles $[8$, p. 58-66]. The researcher speaks of the impossibility of adapting the old methodological principles to new discoveries.

A kind of methodological crisis that has arisen in connection with this can be resolved not along the path of separation and opposition in the content of rational scientific and extra-scientific components, but on the basis of revealing the values of integral forms of consciousness that characterize the integrity of a person's world view. The absolutization of the tradition of "technical" or "technological" rationality leads to the extremes of abstract rationalism, fraught with imposture, faith in the omnipotence of reason and disintegration into self-contained, non-contiguous spheres of being.According to the Belarusian scientist A. Lazarevich, abstract rationalism as a one-sided orientation only to the objective value of knowledge and the effectiveness of its operating, the orientation towards the achievement of the goal and preferably with less means, as like following a certain general legal pattern "denies (up to annihilation) individuality, deprives the knowledge of subjective specificity, makes it impersonal... Therefore, the modern intellectual situation in society should be characterized not only by quantitative and even substantial features of functioning and acquired knowledge, but also by the degree of their subjective (living) explication, including questions of humanism, the practice of moral life, moral and ethical standards"[9, p. 287].

V. Vernadsky emphasized in his time the indissoluble connection of knowledge and morality:"In knowing, our mind does not observe, it forms reality according to the rules of the person...Knowledge of truth requires not only mental ability, and all the feelings, morality, moral responsibility" [10, p. 123].In this context, the role of Ukrainian philosophy in shaping the foundation of new rationalism can not be ignored.In their works, native philosophers have constantly noted that the goal of knowledge is the inner connection of a person with a true being, which anticipates the inclusion of the moral component directly in the process of knowledge.In their interpretation, the rational was considered to be inextricably linked with moral duty, and human activity was conceived on the basis of a deep study of the laws of nature, largely consonant with modern ideas of co-

Humanistic type of rationality as a factor of the formation of co-evolution-innovation strategy for sustainable development of mankind 
evolution.

In the development of the ideas of co-evolution, one should also highlight the role of such a philosophical trend as irrationalism, which has changed the emphasis in the perception of rational and spontaneous, in principle, the nonrational phenomenon of life.It was representatives of irrationalism who for the first time restricted the use of a rational approach to assessing the life of society, stating that a civilization that focuses only on a rational principle and ignores the natural elemental processes inherent in the course of history will end up in a dead end.In contrast to the philosophical classics, which gives the first place to reason and rationality, and the main goal is to identify the internal logic of the development of this rationality,post-classical philosophy marks a refusal to recognize the rational principles of reality and highlights an irrational moment.However, this does not mean a complete denial of both rational in general and the capabilities of the mind in the process of cognition.This is a peculiar change in the alignment of accents, when the place and role of these two all-pervading anthropological and historical constants (rational and irrational) are radically revised.The ideas of the irrationalism theorists clearly demonstrated their significance at the end of the twentieth century, when rationalism, in its usual sense, completely exhausted itself.Although there is a tendency to rationalize the irrational and extraordinary, an exclusively rational approach has turned to mankind for the deployment of a number of global problems, the solution of each of which presents a grandiose in its scale tasks [11, p. 435-436].

The new rationality, which is now being formed on the basis of coevolutionary ethics, allows us to develop an approach to solving global problems that will provide socially constructive solution to the systemic crisis.Along with thist the same time, the idea of co-evolution, which to some extent is present in the works of many researchers, is basically not fully realized now through a rationalistic approach to the world that is firmly rooted in the minds of modern man.In our opinion, this is due to the fact that one of the most vulnerable sides of the concepts now developed, which in various ways involves the implementation of the co-evolutionary principle, is the neglect of one of the most important properties of social systems - their inertia, primarily due to the presence of memory [12, p. 61]. But there is another aspect of the problem. In search of the causes of the current situation, often dehumanizing factors in science are considered to be the growth of the abstraction of scientific constructions, the formalization and mathematization of scientific theories, the technological development of social life and the technological development of social production.Researchers A. Kornienko and An. Kornienko rightly noted that such an interpretation of this order of thingsis an expression of antiscientist positions.Rather, we are talking about the prerequisites for the dehumanization of public life, conditioned by the successes of science [7, p. 25].

It is not about the rejection of 
progress as such, but the necessity of establishing such a science, which is directly related to the solution of fundamental philosophical and general scientific problems affecting the formation of a new type of rationality.If in the course of the natural and social evolution of society, which was under the auspices of nature, it was enough to be guided in the life by the knowledge about the finite, leaving on the "discretion" of nature the relation of the finite and infinite world of nature, then in the conditions of socio-natural development of society, this problem is increasingly relied on humanity. It is not about their opposition, in which one denies the other, since both the first and the second acquire the transcendental status in a new sense.Therefore, the problem of new rationality appears as a problem of the creation of transcendental logic, which expresses the relationship of material and ideal, within which all kinds of creation of nature and man would occupy their place and acquired a common sense.Formation of a new rationality is impossible without changing the system of its basic values, which ensure the stability of the social organism.

Thescientificcommunityingeneralf unctionswithintheframeworkofparadig minstallationsthatwereformedinthesec ondhalfofthetwentiethcentury, anditsconsciousnessoftenremainsinthe depthsofclassicalrationality.It must be understood that the scientific picture of the world has undergone significant changes in comparison with the classical vision, while the universe can continue to be filed within a holistic system bound by common principles. The result of the final stages of ideological and scientific searches of the 70's and 80's of the twentieth century wasthe formation of synergetics in an independent branch of knowledge, which marked the transition to a postmodern science.A new set of categories has been formed, within which the post-nonclassical rationality acquires its outlines.Nature is no longer considered to be an area of the unchanging (deterministic) laws. It is as eventive as history. The synergetic approach and universal evolutionism have become the links that have combined the different picture of the world in some common vision of reality.

The concept of post-classical rationality, which was formed in the twentieth century $[13$, p. $15-26 ; 14$, p. $18-36 ; 15$, p. $21-25]$ is based on the assumption that knowledge of the object are correlated with the mass of its activities and value-target structures.Therefore, it is wrong to understand only what is opposed to the irrational by rational, that is, only logically grounded, existing within the limits of seanse.This is just one of the approaches to determining rational. One should agree with the idea thatitmakesmoresenseto extend rationality to any activity and, if not to solve and if there is no other wayto set the problem of its rationalization and identify its criteria [7, p. 27].

The problem of expanded interpretation of the notion of rational was raised at the turn of the seventeenth and eighteenth centuries, when an attempt was made to

Humanistic type of rationality as a factor of the formation of co-evolution-innovation strategy for sustainable development of mankind 
differentiate the concept of "rationality of knowledge" and "rationality of action".At the same time, rationality was interpreted in a broad sense - as scientifically grounded, organized, accurately and accurately calculated knowledge, ordered according to a certain principle.This is the so-called cognitive sense of the notion of rational knowledge, including scientific as a higher type of rationality.Rational scientific knowledge in the classical sense is knowledge that meets a number of scientific criteria, namely: truth, intersubjectivity (general significance), systemicity, logical inconsistency.But rational can be considered in the broader context taking into account the importance of the social continuum in reforming therationality criteria.We emphasize that rationality is not a specific feature of the sphere of theoretical thinking.Any sphere, which is inherent in value relationships, can be characterized by using the category "rationality".Every spiritual and practical activity that contains elements of the cognitive, and therefore appears as a phenomenon of consciousness, is characterized by rationality.It is clear that the latter does not exclude differences in the criteria of rationality, for example, in scientific, aesthetic or religious activity.

It should be noted that the value and priority status of rationality today is not changing, although its content is acquiring, without a doubt, a new sound.New rationalism requires the approval of semiotic guidelines, which would ensure the co-ordinated development of nature and society.Concepts of arbitrary theories that reflect an immature, transitional state of being should be replaced by concepts confirmed by the practice of a socio-natural whole.

Today, in search of ways of humanizing scientific rationality a new section of the study arose, the essence of which is that understanding the rationality of scientific knowledge is not only variable, but also socially predetermined.Thus, the idea of the criteria for the rationality of scientific knowledge within the German philosophy of the New World differs from that which was formed from the moment when science became a social institution.In science there is a certain connection and complementarity between cognitive criteria of rationality and criteria of sociality.Both the first and the second form a kind of contour, within which "... cognitive criteria of rationality predetermine the specificity of its social criteria, and social criteria of rationality through certain mechanisms affect the formation of cognitive criteria" [16, p. 3-21].And if one can identify the socio-cultural factors that influence the development of science, then the cognitive characteristics of the "hidden" idea of the rationality of social action.Sociodetermined changes in the subject of research appear as a significant factor that determines the kind and type of theory, changes the idea of scientific.Scientific rationality optimizes human activity, due to its possible prediction, it is a means of creating models for the feasibility of changes.Components of science, considered in the dynamics, may be 
deceit, false and partial knowledge, therefore, it is difficult to resolve the rationality of a particular concept or hypothesis at a particular time interval.

Ukrainian scientists claim that the progress of modern scientific knowledge and successes of the synergistic approach lead to the recognition of legitimacy and justification in many epistemological situations of a more "soft" methodology of scientific knowledge (in contrast to the methodology of classical science) in the process of adopting theoretical constructions as scientific.Thus V. Ratnikov submits this methodology in the form of "four refusals": 1) the refusal of the priority of the classical (Laplacian) and quantum-mechanical determinism and the transition to its "softer" forms, which allow a combination (as a complement to each other) of strictly deterministic and probabilistic statistical methods of description, although with possible limitations on the ability of their prediction; 2) the refusal of the priority of linear methods of description, the style of thinking and the transition to nonlinear as more abundant possibilities and realistic, allowing to describe chaotic systems as well;3) the refusal of the priority of simplicity in the scientific description (representation) and the explanation of the world and the expansion of the class of objects possible for scientific research [17, p. 173-174].

The idea of a rational as a multilevel and branched system of categories, in conjunction with the problem of visibility of knowledge, inevitably raises the question of the ideal of rationality.It is intuitively evident that the epistemological ideal of rationality is a scientific theory.Indeed, scientific theory is a special approach to the comprehension of the world, a specific form of knowledge organization, which gives a coherent idea of theexistence laws of the object.Adequacy of reflection, clarity, logical inconsistency of the structure of knowledge within the theory, systematic and internal structuring of scientific knowledge, completeness and practical significance-all this makes scientific theory an ideal of rationality.In the process of a theory development, the theoretical means of presentation of knowledge are worked out, procedures are carried out for its systematization, which theorizes and rationalizes science.It is the formation of scientific theory that determines the highest characteristics of rationality: universality, necessity, authenticity, methodological performance and practical significance.In historical terms, the very process of theorization as the basis for a rational reconstruction of the science development is no less important than the creation of a scientific theory for the science. Research thought moves from ideal scientific theories to hierarchies, which are based on fundamental theories [18, p. 13-26].

Confirmation of the mentioned is the factthat the social system never completely loses the memory of its prehistory, since the consciousness of people is rather conservative and difficult to refuse stereotypical representations. That is why the idea of

Humanistic type of rationality as a factor of the formation of co-evolution-innovation strategy for sustainable development of mankind 
synthesis of western and eastern cultures today is of great popularity, based on changing patterns of behavior of politicians, representatives of different religions, scientists and businessmen, which, according to its founders, is intended to serve as the basis for a new rationality. We believe that the traditionalist-type civilization will not accept unambiguously Western values, as well as man-made - the values of Eastern culture. The process of interpenetration and the establishment of stable ties between the two cultures on the basis of the ideas of co-evolution may prove to be as prolonged and complicated as unpredictable obstacles that the time humanity has to deal with global problems can be disastrously little.In view of the above, optimism about a possible intergenerational combination on the basis of coevolutionary processes of the Eastern and Western cultures is to a certain extent premature [12, p. 61].

However, in the search for ways to make the subject of scientific knowledge the most refined aspects of spiritual life and human experience, synthesis of Eastern and Western religious, philosophical, spiritual and scientific traditions is required.A notable feature of Oriental cultures is the development of ideas of harmony of truth and morality, designed through the prism of scientific and technological progress, which can provide a philosophical and methodological foundation for nondestructive research of humandimensional developing systems.Recently, concepts that somehow involve inclusion in the civilization of the society of elements of Eastern cultures, determine one of the key trends in the attempts to solve the problem of changing the values grounds of thesociety foundations.

However, typical for technogenic civilization idea of a person as an active transforming subject is in a rigid opposition with typical for the Oriental culture views on the admissibility of only the minimum necessary impact on the surrounding world.In our opinion, this opposition does not allow us to hope for the prospect of rapid formation of harmonious synthesis of western and eastern cultures with the subsequent restoration of the original balance of man and nature in the individual concepts described.Since the return to the natural environment for humankind has become fundamentally impossible, the characteristic feature of the above concepts are considered somehowutopian.

For the practical realization of these concepts, it is vital, in our opinion, to create a mechanism capable of effectively overcoming the inertia of the society, due to the presence of memory of the prehistory and the stereotypes that are formed on its basis.The role of such a mechanism, in our opinion, is capable of performing innovative activity on the basis of co-evolutionary ethics.The combination of the coevolutionary strategy of the society with the innovative approach, serving as an instrument of advanced actualization and the choice of viable forms, allows us to provide a more harmonious perception of the values system, tested by a combination of natural evolution and a proactive participation of the human mind.In this sense, rationality, based on coevolutionary innovation ethics, 
provides society with a high level of resilience to the devastating effects of crises.It is innovative activity, as an instrument of a pre-emptive actualization and the choice of a possible future, is capable of supporting the process of society socialization. The latter is based on the search and forecasting function of innovation, and therefore has the potential to develop a strategy for the timely and successful solution of evolutionary crises.

A society of sustainable development is impossible without a significant self-limitation of a person, their needs and claims. The concept of intelligent needs, which should be steadily guided by mankind, is logically connected with the study of Academician V. Vernadsky about the noosphere - the sphere of mind, as a new stage in the evolution of the biosphere, associated with the emergence of human consciousness and aimed at transformation of nature activities. The key idea of the researcher is that the transition of the biosphere to the noosphere, that is, the realm of reason, is a logical and inevitable stage in the development of mankind.A man, according to $\mathrm{V}$. Vernadsky, is not a self-sufficient living being, living separately according to his / her own laws, it coexists within nature and is part of it.Noospherization (that is, filling with intelligent content) of literally all spheres of life of society is the most important, truly strategic requirement of time $[19 ; 20]$.The doctrine of the noosphere became the stimulus for the formation of a new picture of the world, aimed primarily at knowledge as the truth in knowledge, and not the conquest of the laws of nature (ecological imperative), the revision of the whole set of traditional ideological notions about the place and role of man in nature and society, the discovery of new values, priorities and norms of being of society.

Today, nature faces the humanity with the "imperative of survival" as an imperative of transition to a new form of being - the noosphereecologically spiritual one, the model of the noosphere as a controlled socionatural evolution based on social intelligence and an educated society.Therefore, the problem of the formation of noosphere anthropocentrism and human thinking is acute.Only "noosphere man" can think not only in the aspect of a separate personality, family or kind, state or their associations, but also on a world-wide basis.Noosphericism is not only a new form of being, a socionatural homeostasis, but also a new philosophy, a new scientific picture of the world, a new quality of a man.

Confirmation of the above is the opinion of the authors of the monograph "Philosophy of Information and Communicative Society: Theoretical and Methodological Context" concerning the future: "Philosophy of noosphere development means that politics is defined by the sphere of mind (noosphere), morality and justice, is based on a scientific, rational and moral basis of justice, on noospheric approaches to the development of society ...The criterion for thedevelopment level and quality of human life is the humanistic values

Humanistic type of rationality as a factor of the formation of co-evolution-innovation strategy for sustainable development of mankind 
and knowledge of a person who lives in harmony with the surrounding nature and the natural environment"[21, p. 224].

Consequently, a knowledge-based information society based on sustainable development can be considered as the first stage of the sphere of mind, where the dominant resource is the information used for the purpose of sustainable development, and information technologies are the main source of further noosphereogenesis. The selforganization of the noosphere as a globally sustainable socio-natural system is carried out here by minimizing the use of material and energy resources, preserving the biosphere.The upcoming step of noospherogenesis, on the thought of the military writer V. Voronkovo, is the entry of the organization into the epoch of ecologic civilization, which will be based on effective solutions to the problems of protecting the environment,sustainable use of natural resources and the prevention of anthropogenic ecological catastrophe, where environmental safety should be immanently interconnected with sustainable socioeconomic development of the noosphere orientation. Development of a universal program of human survival involves the need to implement the noospheric and ecological imperative in the practice of human life, developing the need for each person to be responsible for the future of civilization and for the fate of the human race,which should be the basis of "global ethics", based on the idea of human ecology and its spiritual and moral perfection through awareness of itself as part of the socio-natural integrity [22, p. 179-191].

Studying the situation, Ukrainian researchers came to the conclusion that the breakthrough in the system of information and communication technologies caused profound meaningful changes in all spheres of social and professional activity that led to the emergence of a new phenomenon of smart-society and a smart-man. The concept of smartsociety as the highest stage of civilization development requires implementation at all levels of human development, which indicates a high ranking of the country in terms of innovation development [23; 24; 25].Currently, the ideas of quantum physics (quantum consciousness), the theory of the holographic universe, the ideas of cholodynamics, bodyoriented therapy, neurobiology, etc., which prove the unity of all existing, and the concept of synergy, synchrony is used as the key in various sciences.Therefore, the question of new ways of learning and a new scientific paradigm has become acute.

The present situation can be changed by providing the scientific progress with a new direction, forming a humanistic dimension of scientific rationality, harmonized with the sphere of social relations, making man-centered landmarks determining in the evolution of science as a sphere of knowledge.Only after fully comprehending the sociality of science, its connection with the culture of civilization, a person will be able to humanize science.As a result, a person has to solve the issue of scientific rationality from the standpoint of humanistic world 
perception, and thus create a new humanistic model of science.

The basis for solving this problem may be a new understanding of humanism, which, in turn, will serve as the basis for the formation of a new, humanistic type of rationality.This means that the problem of synthesis "man - science humanism" should acquire a fundamentally new twist.If the traditional concept is based on the interpretation of humanism as a valueoriented relationship, focused on a man, then anthropocentrism makes man the center and unsurpassed goal of the universe.Thus, the humanistic tradition derives from the recognition of the value of man as a person, the recognition of the human good as a criterion for assessing of all social structures and the recognition of person as the highest goal[7, p. 29].Today, the situation for generating new generalized philosophical concepts is quite favorable.Fundamental sciences have made new developments that require a broad conceptual synthesis, so there is a need to create a new ideological paradigm [26, p. 53-60; 27, p. 28-38].

Today, the "human gap" that penetrates information and technological civilization is becoming more and more visible.Especially strongly it manifests itself in the isolation of science and technology from humane relations problems.Indeed, the 21 st century is a century of information, science and technology.Unprecedented in history, scientific and technological progress, the power of material objects, penetrating all hypostasis of human existence, affects both the state of the Spirit and soul, interpersonal and interstate relations.Politics, art, religion, morality almost as much as the economy, being under the authority of the "technical demon", appear in the form of fetishized computer entities, the transnational being of which forms the state of the social spirit, its customs, social feelings and emotions, behavioral reactions, and motives of activity.In a modernizing society, people begin to act rationally in all spheres of being, lose their habits of navigating life only on traditional representations, to build it on illusions and fantasies, no matter how attractive and comforting they are.

It is no exaggeration to assertthat the basis of all problems of our time is the anthropological crisis, conditioned by the underestimation of the spiritual and moral aspects in the human life of industrial and postindustrial society.In the commemorative report "Come On!"the co-presidents of the Roman Club Anders Wijkman and Ernst Ulrich von Weizsekker, in collaboration with more than 30 members of the Committee, featured a new paradigm for resolving global economic, social and environmental crises. The leading role is played by the idea of a new "Enlightenment" for the "Complete World": we can not continue to live according to old models created for the world with less than a billion people.The existing development model is fundamentally fallacious, and the maximization of profits and the salvation of the planet is controversial.The new "Enlightenment" should be

Humanistic type of rationality as a factor of the formation of co-evolution-innovation strategy for sustainable development of mankind 
characterized by a substantially improved balance between man and nature, between markets and the law, between private consumption and public goods, between social justice and development incentives [28].

Today, when humankind has not only comprehended the "limits of growth", but actually reached them, a qualitatively new paradigm is required.This is what "Come On!" calls "New Enlightenment."The ideology of balance between man and nature; between long-term consequences and tactical tasks; between speed and stability; between personal and social; between religion and state; between fair remuneration and social equality; between market forces and the law.It's worth consentingeщ the authors of "Come On", who combine economics, politics, ecology and even philosophy and psychology, contrasting the new anthropocentrism to the obsolete market fundamentalism.

Solving the problem is the formation of human integrity by overcoming the gap between scientific rationality and cultural values.A person should find new forms of connection between scientific rationality and spiritual and moral values, should need higher values more than benefit and profit.However, the awareness of the need to rethink the current situation, when scientific knowledge and rationality based on it are opposed to spiritual and moral values or are indifferent to them, is rather slow.

It should be noted that in connection with the rise of the economic and cultural potential of society, the importance of free time, rationalization and culture of leisure increase, which is organically linked with the improvement of the whole system of social relations. Therefore, not only social and political-economic institutions must be transformed, but also totalitarian forms of traditional culture that contribute to the ideological strengthening of social amnesia, consumer irrationalism and dehumanized consumption fetishism.

Social life today is filled with uncertainty, risks, conflicts, and with each subsequent change, it is becoming increasingly difficult to predict even the immediate future.Social governance and sociality as a whole, based on rational strategies, become ineffective under current conditions. Knowledge in itself did not justify those hopes and expectations that relied upon them from the era of the Enlightenment.This knowledge turned out to be insufficient to find effective ways of arranging the world on both reasonable and humanistic grounds. Is it actually possible, on the basis of a rational approach, to understand and predict the development of the modern world of society?

The concept of humanism that is being formed today, unlike the previous one, does not separate a person in the world, and the more it does not contradict them, but considers a person in a world that serves for their self-worth, and hence the value of knowledge must be determined not by its concrete, temporary utility, dictated by the "principle of consumption", but by the fact that knowledge is the soul of human culture, the entire history of scientific and spiritual civilization, that is also self-sufficient.That is all that, being an intrinsic value, becomes a 
value for a person.Therefore, nowadays the dehumanization of science, modern scientific rationalism, manifested in the loss of communication between science and man, in the technization of science, in alienating knowledge from the one who produces it, can only be overcome through a humanistic approach to rationality.

For terrestrial civilization, at the present stage of its evolution, the transcendental social and transcendental spirit, we believe, will remain the subject of non-scientific knowledge, since the terrestrial civilization faces more urgent problem of preserving life as such.Without a rational solution of the latter, the problems of higher forms of rationality lose meaning and sense.

Therefore, the main efforts in solving the problem of new rationality now, obviously, should be aimed at the formation of a new scientific rationality, able to explain and save the alive and life.

The task is not to question the possibility of scientific rationalism in the name of some other ideological system.It is important to formulate other requirements for rationalism, conditioned by the realities and requirements of modern society.Social practice of the end of the XX beginning of the XXI century evidenced not so much the falsehood of scientific rationalism as the false opposition of thinking and faith, feeling.Today, a system of rationalism combining both science and morality, reason, and feeling, and humanism in its basis is required.

There is one way out, in our opinion, to unite the efforts of natural scientists and humanities scholars, theorists and practitioners to ensure the priority development of basic and applied research.

After all, only such an order of thingsis normal in the conditions of society's transition from a naturalsocial evolution to a socio-natural development, when humanity assumed responsibility for the situation not only in society, but also in its development of the environment.The principles of justice, liberal democracy, everything in society acquires its true meaning and higher rationality, if they are aimed at the good of man.

\section{Conclusionsandpracticalrecomm endations}

Conclusions.Rationalism has initiated practical and utilitarian aspirations and ambitions that became a norm for most industrialized countries, in the ideological basis of which are such components of intellectual paradigms as pragmatism, technicalism and scientism, which reduce the role of values, especially moral ones, to a minimum.

It is the classical rationality that generated the Western technological civilization with its system of values and ideological systemswhich put mankind in front of the alternative "to be or not to be".

Humanity, which desires to institute a humane society on a scientific basis, must form a notion of science, which allows us to introduce the human factor in the criterion of scientific rationality.

Methodologically, this means the priority position of the humanistic

Humanistic type of rationality as a factor of the formation of co-evolution-innovation strategy for sustainable development of mankind 
criteria of scientific rationality in relation to others. Scientific rationality in this case loses its previous property to be self-worth, since it acquires a fundamentally new characteristic and becomes the expression of the essential forces of man, acquires human qualities.

\section{REFERENCES}

1. Tolstoukhov, A. V. (2003). Globalnyi sotsialnyi kontekst i kultury ekobudushchego. Voprosy filosofii, 8, 49-63.

2. Kasavin, I. T., Lektorskii, V. A. and Shvyrev, V. S. (2005). Staryi i novyi ratsionalizm. Dialog kultur $\mathrm{v}$ globaliziruiushchemsia mire: mirovozzrencheskie aspekty. V. S. Stepin, A. A. Guseinov (Eds). Moskva: Nauka, 65-73.

3. Reimers, N. F.and Shuper, V. A. (1991). Krizis nauki ili beda tsivilizatsii? Voprosy filosofii, 6, 68-75.

4. Merse, Andre. (1989). Nauka stala agressivnoi... Dialogi prodolzhaiutsia: o vozmozhnykh posledstviiakh razvitiia sovremennoi nauki. Moskva: Politizdat, 7-14.

5. Stepin, V. S. (2003). Samorazvivaiushchiesia sistemi i postneklassicheskaia ratsionalnost. Voprosy filosofii, 8, 5-17.

6. Khabermas, Iu. (2000). Moralnoe soznanie i kommunikativnoe deistvie. SPb.: Nauka, 384.

7. Kornienko, A. A. and Kornienko, An. A. (2011). Gumanisticheskie kriterii ratsionalnosti $\mathrm{V}$ postneklasicheskoi nauke: kontseptsii novogo ponimaniia gumanizma. Vestnik Buriatskogo gosudarstvennogo universiteta. Vupysk 14. Filosofiia, sotsiologiia, politologiia, kulturologiia. Ulan-Ude: Izd-vo Buriatskogo gosuniversiteta, 25-30.

8. Cyra, O. V. (2019). Unikaljnistj jak forma zv'jazku ta zaperechennja u rozvytku typiv racionaljnosti. Humanities Bulletin of Zaporizhzhe State Engineering Academy, 76, 5668.

9. Lazarevich, A. A. (2008). Globalnoe kommunikatsionnoe obshchestvo. Minsk: Belorus. nauka, 350.

10. Vernadskii, V. I. (1991). Nauchnaia misl kas planetarnoe avlenie. Moskva: Mysl, 233.

11. Irratsionalizm. Vsemirnaia entsiklopediia: Filosofiia. A. A. Gritsanov (Ed.). (2001). Moskva: AST, Minsk: Kharvest, Sovremennyi literator, 435-436.

12. Nikitina, Iu. A. (2009). Izmenenie osnovanii ratsionalnosti kak faktor formirovaniia koevoliutsionno-innovatsionnoi strategii sotsiuma. Vestnik Buriatskogo gosudarstvennogo universiteta. Filosofiia, sotsiologiia, politologiia, kulturologiia. Ulan-Ude, Izd-vo Buriatskogo gosuniversiteta, 14, 58-62.

13. Lektorskii, V. A. (2004). Vozmozhna li integratsiia estestvennykh nauk i nauk o cheloveke. Voprosy filosofii, 3, 15-26.

14. Rats, M. (2002). Voinstvuiushchii ratsionalizm ili «razumnaia ratsionalnost». Voprosy filosofii, 6, 18-30.

15. Shakirova, E. Iu. (2012). Ratsionalizm: tupik ili vykhod iz krizisa? Novyi universitet: nauchnyi zhurnal. Seriia «Aktualnye problemy gumanitarnykh i obshchestvennykh nauk». Ioshkar-Ola, 9 (18), 21-25.

16. Nauka i kultura: materialy kruglogo stola (1998). Voprosy filosofii, 10, 3-21.

17. Ratnikov, V. S. (2004). Nauchnaia ratsionalnost: na puti k obnovleniiu kriteriev i idealov. Sententiae: Naukovi praci Spilky doslidnykiv modernoji filosofiji (Paskalivsjkogho tovarystva). Specvypusk 1 «Fenomen racionaljnosti», 150-176.

18. Nugaev, R. M. (2002). Smena razvitykh nauchnyk hteorii: tsennostnye izmereniia. Voprosy filosofii,11, 13-26.

19. Vernadskii, V. I. (1988). Filosofskie mysli naturalista. AN SSSR, A. L. Ianshin (Ed.) etal., M. S. Bastrakova (Ed.) etal.Moskva: Nauka, 520.

20. Vernadskii, V. I. (1989). Biosfera i noosfera. Moskva: Nauka, 261.

(C) Kozlovets Mykola \& Horokhova Liudmyla \& Melnychuk Victoriia, 2019 
21. Voronkova, V.H., Sosnin, O. V., Nikitenko, V. O. and Maksymenyuk, M. Yu. (2016). Filosofija informacijno-komunikatyvnogho suspiljstva: teoretyko-metodologhichnyj kontekst: monoghrafija. V. Gh. Voronkova (Ed.). Zaporizhzhia: Zaporizka derzhavna inzhenerna akademiya, 276.

22. Voronkova, V. H. (2016). The Formation of the Concept of Noosphere Development of Modern Society in the Conditions of Information Society. Philosophy and Cosmology, 16. Kyiv: ISPC, 179-191.

23. Andriukaitiene, R., Voronkova, V. H., Kyvliuk, O. P. and Nikitenko, V. A. (2018). Stanovlenie i razvitie smart-obshchestva kak vysokorazumnogo, vysokotekhnologicheskogo, vysokointellektualnogo. Humanities Bulletin of Zaporizhzhe State Engineering Academy, 71, 17-26.

24. Voronkova, V. H., Kyvljuk, O. P. and Andriukaitiene, R. (2017). Konceptualizacija modeli noosfernogho rozvytku suchasnogho sociumu ta osvity informacijnogho suspiljstva. Humanities Bulletin of Zaporizhzhe State Engineering Academy, $68,33-48$.

25. Vyshnevsjkyj, M. I. (2018). Filosofsjka osvita u kontekstiideji smart-suspiljstva. Humanities Bulletin of Zaporizhzhe State Engineering Academy, 74, 122-128.

26. Oleinikov, Iu. V. (2015). Stanovlenie novoi mirovozzrecheskoi paradigmi. Filosofskie nauki, 10, 53-60.

27. Korsak, K. V. and Korsak, Ju. K. (2018). Jedynyj shljakh porjatunku ljudstva vid totaljnogho kolapsu - nootekhnologhiji ta noonauky. Humanities Bulletin of Zaporizhzhe State Engineering Academy, 74, 28-38.

28. Weizsaecker, E. and Wijkman, A. (2018). Come On! Capitalism, Short-termism, Population and the Destruction of the Planet. Springer, 220.

КОЗЛОВЕЦЬ, М. А. - доктор філософських наук, професор, професор кафедри філософії Житомирського державного університету імені Івана Франка (Житомир, Україна)

E-mail: mykola.kozlovets@ukr.net, ORCID iD: 0000-0002-5242-912X

ГОРОХОВА, Л. В. - кандидат філософських наук, доцент кафедри філософії Житомирського державного університету імені Івана Франка ( Житомир, Україна)

E-mail:_glv@ukr.net, ORCID iD: 0000-0002-5114-523X

МЕЛЬНИЧУК, В. В. - кандидат філософських наук, доцент кафедри суспільних наук Житомирського національного агроекологічного університету (Житомир, Україна)

E-mail:vikam1804@gmail.com, ORCID iD: 0000-0003-1569-3201

\section{ГУМАНІСТИЧНИЙ ТИП РАЦІОНАЛЬНОСТІ ЯК ЧИННИК ФОРМУВАННЯ КОЕВОЛЮЦЙНО-ІННОВАЦЙНОЇ СТРАТЕГІЇ СТАЛОГО РОЗВИТКУ ЛЮДСТВА}

Анотація. Актуальність дослідження полягає в тому, що сучасна раціональність як значне досягнення цивілізації стає водночас і реальною загрозою для людства. Наука, виконуючи гуманістичну місію, разом з тим дегуманізує те, на що була спрямована : систему цінностей, освіту і культуру. Набуті знання часто використовуються для знищення довкілля і людства, а не для прогресу та добробуту. Порушення гармонії природного, соціального і духовного, недооцінка антропоцентричного виміру наукової раціональності поставили на межу буття Homo sapiens. У філософській та суспільній думці останнім часом особливої актуальності набуває проблема шляхів формування нового гуманістичного світовідношення і гуманістично орієнтованої науки, етичної раціональності. Аналіз літератури. Використані праці зарубіжних та вітчизняних

Humanistic type of rationality as a factor of the formation of co-evolution-innovation strategy for sustainable development of mankind 
авторів, в яких розпочато дослідження цієї проблеми: Р. Андрюкайтене, В. Вернадського, М. Вишневського, В. Воронкової, Ю. Габермаса, О. Грицанова, I. Касавіна, А. Корнієнко, К. Корсака, А. Лазаревича, В. Лекторського, А. Мерсьє, М. Моїсеєва, Р. Нугаєва, В. Ратнікова, О. Сосніна, В. Стьопіна, Ю. Нікітіної, М. Раца, Н. Реймерса, А. Толстоухова, О. Цира, В. Швирьова, В. Шупера. Мета статті філософське осмислення нової раціональності як чинника формування коеволюційноінноваційної стратегії розвитку сучасного світу. Завданням дослідження $є$ аналіз сутності раціональності, характеристика іiі основних ознак та ролі у формуванні коеволюційно-інноваційної стратегії сталого розвитку людства. Методологія дослідження грунтується на міждисциплінарному підході, що інтегрує сучасні напрацювання філософії, філософії науки, епістемолології, екології, етики та аксіології. Осмисленню складних проблем дихотомії "раціональне / ірраціональне", "еволюція / коеволюція", "криза / сталий розвиток" та їх вливу на гуманізацію наукового знання сприяло використання принципів історизму і глобального еволюціонізму, діалектичного методу, методів абстрагування, узагальнення й концептуалізації, а також методології та принципів синергетики.

Результати дослідження: у статті розглянуто сутність раціональності та обмеженість нині діючої іï концепції, причини та особливості кризи раціонального усвідомлення сучасного світу,зумовленої дегуманізуючою роллю науково-технологічного прогресу. Обгрунтовано тезу, що ситуацію можна змінити, надавши науковому прогресу гуманістичного спрямування, сформувавши антропоцентричний вимір наукової раціональності. Людство повинно вирішити питання про раціональність 3 позиції гуманістичного світовідношення і створити нову модель науки. Підставою для розв'язання цієї проблеми може виступити сучасне розуміння гуманізму, що, у свою чергу, слугуватиме підгрунтям для виникнення новітнього типу раціональності. Саме раціональність, яка формується на основі етики гуманізму, спроможна стати стрижнем коевоційно-інноваційної стратегії сталого розвитку людства.

Висновки дослідження полягають у тому, що саме гуманістична раціональність, яка грунтується на коеволюційно-інноваційній етиці, забезпечує глобалізованому соціуму як системі високий рівень стійкості щодо руйнівного впливу криз, формування інноваційної орієнтації 3 врахуванням необхідності подолання потенційно небезпечного розриву між сучасними цивілізаціями- науково-технологічною i суспільно-гуманістичною.

Ключові слова: раціональність, ірраціональність, наука, наукова раціональність, типи раціональності, коеволюція, інновація, науково-технологічний прогрес, постнекласичний гуманізм.

КОЗЛОВЕЦ, Н. А. - доктор философских наук, профессор, професор кафедры философии Житомирского государственного университета имени Ивана Франко (г. Житомир, Украина).

E-mail: mykola.kozlovets@ukr.net, ORCID iD : 0000-0002-5242-912X

ГОРОХОВА, Л. В. - кандидат философских наук, доцент кафедры философии Житомирского государственного университета имени Ивана Франко (г. Житомир, Украина).

E-mail:_glv@ukr.net, ORCID iD : 0000-0002-5114-523X

МЕЛЬНИЧУК, В. В. - кандидат философских наук, доцент кафедры общественных наук Житомирского национального агроэкологического университета (г. Житомир, Украина).

E-mail: vikam1804@gmail. com, ORCID iD: 0000-0003-1569-3201

(C) Kozlovets Mykola \& Horokhova Liudmyla \& Melnychuk Victoriia, 2019 


\title{
ГУМАНИСТИЧЕСКИЙ ТИП РАЦИОНАЛЬНОСТИ КАК ФАКТОР ФОРМИРОВАНИЯ КОЭВОЛЮЦИОННО-ИННОВАЦИОННОЙ СТРАТЕГИИ УСТОЙЧИВОГО РАЗВИТИЯ ЧЕЛОВЕЧЕСТВА
}

\begin{abstract}
Аннотация. Актуальность исследования состоит в том, что современная рациональность как значительное достижение цивилизации становится одновременно и реальной угрозой для человечества. Наука, выполняя гуманистическую миссию, вместе с тем дегуманизирует то, на что была направлена: систему ценностей, образование и культуру. Приобретенные знания часто используются для уничтожения окружающей среды и человечества, а не для прогресса и благополучия. Нарушение гармонии природного, социального и духовного, недооценка антропоцентрического измерения научной рациональности поставили на грань бытия Homo sapiens. В философской и общественной мысли в последнее время особую актуальность приобретает проблема путей формирования нового гуманистического мироотношения и гуманистически ориентированной науки, этической рациональности. Анализ литературы. Использованы труды зарубежных и отечественных авторов, в которых начато исследование этой проблемы: Р. Андрюкайтене, В. Вернадского, М. Вишневского, В. Воронковой, Ю. Хабермаса, А. Грицанова, И. Касавина, А. Корниенко, К. Корсака, А. Лазаревича, В. Лекторского, А. Мерсье, Р. Нугаева, В. Ратникова, О. Соснина, В. Степина, Ю. Никитиной, М. Раца, Н. Реймерса, А. Толстоухова, О. Цира, В. Швырева, В. Шупера. Цель статьи - философское осмысление новой рациональности как фактора формирования коэволюционный-инновационной стратегии развития современного мира. Задачей исследования является анализ сущности рациональности, характеристика её основных признаков и роли в формировании коэволюционный-инновационной стратегии устойчивого развития человечества. Методология исследования основывается на междисциплинарном подходе, интегрирует современные наработки философии, философии науки, эпистемолологии, экологии, этики и аксиологии. Осмыслению сложных проблем дихотомии "рациональное / иррациональное", "эволюция / коэволюция", "кризис / устойчивое развитие" и их влиянию на гуманизацию научного знания способствовало использование принципов историзма и глобального эволюционизма, диалектического метода, методов абстрагирования, обобщения и концептуализации, а также методологии и принципов синергетики.
\end{abstract}

Результаты исследования: в статье рассмотрены сущность рациональности и ограниченность ныне действующей её концепции, причины и особенности кризиса рационального осознания современного мира, обусловленного дегуманизирующей ролью научно-технологического прогресса. Обоснованно тезис, что ситуацию можно изменить, придав научному прогрессу гуманистического направления, сформировав антропоцентрическое измерение научной рациональности. Человечество должно решить вопрос о рациональности с позиции гуманистического мировоззрения и создать новую модель науки. Основанием для решения этой проблемы может выступить современное понимание гуманизма, что, в свою очередь, послужит основой для возникновения нового типа рациональности. Именно рациональность, которая формируется на основе этики гуманизма, способна стать стержнем коэвоционноинновационной стратегии устойчивого развития человечества.

Выводы исследования состоят в том, что именно гуманистическая рациональность, основанная на коэволюционно-инновационной этике, обеспечивает глобальному социуму как системе высокий уровень устойчивости относительно разрушительного воздействия кризисов, формирование инновационной ориентации с учётом необходимости преодоления потенциально опасного разрыва между

Humanistic type of rationality as a factor of the formation of co-evolution-innovation strategy for sustainable development of mankind 
современными цивилизациями - научно-технологической и общественногуманистической.

Ключевые слова: рациональность, иррациональность, наука, научная рациональность, типы рациональности, коэволюция, инновация, научно-технологический прогресс, постнеклассический гуманизм.

Стаття рекомендована до публікаиії

д. філос. н., проф. В. Г. Воронковою (Запоріжжя, Україна)

Надійшла до редколегіï: 12.06.2019 p.

Прийнята до друку: 17.06.2019 р. 